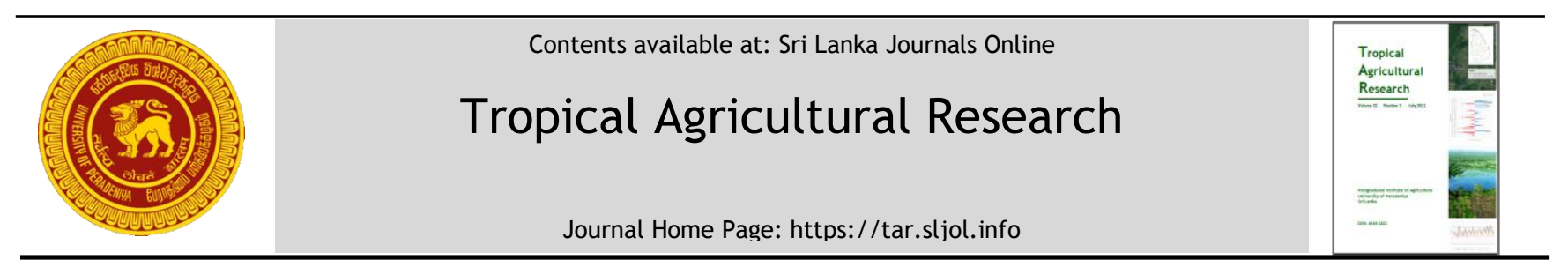

\title{
Comparison of DNA Extraction Protocols for Molecular Identification of Root Knot Nematode (Meloidogyne Spp.) Using Egg Masses
}

\author{
W.M.S.U.K. Wijekoon ${ }^{1}$, K.M.D.W.P. Nishantha ${ }^{2}$ and D.M De Costa ${ }^{1^{*}}$ \\ ${ }^{1}$ Postgraduate Institute of Agriculture, University of Peradeniya, Sri Lanka. \\ ${ }^{2}$ Horticultural Crop Research and Development Institute, Gannoruwa, Peradeniya, Sri Lanka.
}

\section{ARTICLE INFO}

\section{Article history:}

Received: 15 August 2020

Revised version received: 16 December 2020

Accepted: 20 January 2021

Available online: 30 July 2020

\section{Keywords:}

DNA isolation methods,

Meloidogyne,

PCR amplification, $1 \%$ SDS.

\section{Citation:}

Wijekoon, W.M.S.U.K., Nishantha, K.M.D.W.P., and De Costa, D.M. (2022). Comparison of DNA extraction protocols for molecular identification of root knot nematode (Meloidogyne Spp.) using egg masses. Tropical Agricultural Research, 32(3): 318-324.

DOI: http://doi.org/10.4038/tar.v32i3.8495

Wijekoon, W.M.S.U.K.

https://orcid.org/0000-0001-7124-3868

\section{ABSTRACT}

There is a dire need of alternative reliable and non-laborious methods with high resolution for identification of the root-knot nematodes at the species level where molecular techniques have shown the potentials. This study assessed four DNA extraction protocols, (i.e. TNES buffer method, Modified CTAB method, Phenol / Chloroform Method and 1\% SDS method) to extract DNA from egg masses of root knot nematodes. Egg masses were collected from pure cultures of nematodes maintained in tomato cultivation under net house condition. After extraction of genomic DNA, Polymerase Chain Reaction was performed to determine the success of the method of DNA extraction. The $1 \%$ SDS method with incubation at $-20{ }^{\circ} \mathrm{C}$ for 1 $\mathrm{hr}$ and incubated at $65{ }^{\circ} \mathrm{C}$ for $1 \mathrm{hr}$ and again incubated for $95{ }^{\circ} \mathrm{C}$ for $10 \mathrm{~min}$, was a better method to result in intense PCR bands of the expected sizes (720 bp and $999 \mathrm{bp}$ ) when amplified by Meloidogyne genus and Meloidogyne incognita specific primers. This DNA extraction procedure could contribute as an effective method to molecular identification of species and other downstream applications of population studies of root knot nematodes.

\footnotetext{
*Corresponding author: devikadecosta@gmail.com
} 


\section{INTRODUCTION}

Nematodes are ubiquitously present multicellular organisms which belong to a diversified taxonomic group of the phylum Nematoda. Root-knot nematodes belong to the genus Meloidogyne, that consists of more than 100 species and are polyphagous endo-parasites of the root systems of various trees, shrubs and herbaceous plants in the tropics and subtropics (Sikora et al., 2018). Conventionally, morphometric values and female perineal patterns are used for identification of Meloidogyne species which are based on less expensive methods but needs highly-skilled experts (Bogale et al., 2020). Even though, classical methods based on morphological and anatomical characters are sufficient enough to identify major species of Meloidogyne, with the discovery of many new species, these methods became inadequate as those characters overlap between species (Brito et al., 2004; Villar-Luna et al., 2016).

Moreover, due to high genetic, morphological and biological diversity in Meloidogyne spp., classical identification methods become complex, timeconsuming and sometimes inaccurate. According to Eisenback (1985) and Cliff et al., (1985), precise and reliable identification at species level is a difficult task for the genus Meloidogyne, even for well qualified taxonomists. In this connection, as an alternative and a polyphasic approach, a wide range of molecular methods (i.e., DNA-based and protein-based) have been introduced (Bogale et al., 2020). Unlike morphology based methods, molecular methods can be performed with medium level expertise to achieve more accurate identification of species (Bogale et al., 2020). As reviewed by Bogale et al., (2020), DNA analyses based on genomic fingerprints and nucleotide sequences are in heavy use for identification of species of these nematodes. To this end, DNA of high quality, quantity and integrity is an essential prerequisite.

To achieve species identification, DNA extraction has to be done using individual nematodes to eliminate the possible mixing up of different species, when nematodes are extracted from soil and root samples. Most of the DNA extraction protocols available in literature have been attempted using second stage juveniles of Meloidogyne spp. (Mondino et al., 2015; Adam et al.,2007). Extraction of individuals at different growth stages from environmental samples and hand-picking those individually upon extraction under a microscope are time consuming and tedious tasks. Egg masses of Meloidogyne spp. can be separated from infected roots with an unaided eye and a single egg mass harbours several hundreds of eggs. Therefore, egg masses are an ideal source of genomic DNA of Meloidogyne spp. and it will avoid time consuming and tedious preparatory steps of DNA extraction.

Plenty of DNA extraction methods have been reported for extract DNA from single juveniles to a large number of juveniles, eggs or adult females. These methods are based on phenol-chloroform extraction or salting out of DNA. In addition, commercial kits based on DNA binding to silica columns and magnetic based-surfaces are available at higher prices. Phenol/Chloroform basedmethods are widely used even before the introduction of commercial kits and they are still providing satisfactory results with high quality DNA (Christoforou et al., 2017). However, toxic effects and higher time consumption have been reported as the disadvantages of phenol/chloroform based extraction methods (Christoforou et al., 2017; Chacon-Cortes et al., 2012). Therefore, the present study was conducted to select an effective DNA extraction protocol using egg masses of Meloidogyne spp. by comparing a few available in literature.

In Sri Lanka, the nematodes which belong to the genus Meloidogyne cause a significant crop loss and impact on economic returns in almost all crops grown. Correct identification, determination of infestation level and mapping of nematode incidences at species level are of paramount importance in decision making on crop establishment and site-specific nematode management. Therefore, findings of the study will be helpful to minimize agrochemical usage and expenditure incurred on nematode management assuring sustainable agricultural production with lower pest damages while ensuring the product, farmer and environmental safety.

\section{METHODOLOGY}

\section{Sample collection and extraction of egg masses}

Egg masses were collected from stressed and stunted tomato plants which were introduced with pure cultures of nematodes grown under net house conditions at the Entomology Division, Horticultural Crop Research and Development Institute (HORDI), Gannoruwa, Peradeniya during the period of October to January 2019/2020.

Collected root samples were cleaned with running tap water and egg masses were separated using 
sterilized scalpel blade and forceps. The egg masses were collected into the microcentrifuge tubes $(1.5 \mathrm{~mL})$ and those samples were used for the DNA extraction process (Daramola et al., 2015).

Experiments on molecular analyses were conducted at the Plant Pathology and Microbiology laboratory in the Department of Agricultural Biology, University of Peradeniya and Virology laboratory, Horticultural Crop Research and Development Institute (HORDI), Gannoruwa, Peradeniya.

\section{DNA extraction from nematode egg masses}

Subsamples were prepared using four nematode egg masses per single microcentrifuge tube $(1.5$ $\mathrm{mL}$ ) with $10 \mu \mathrm{L}$ of autoclaved distilled water and stored at $-20{ }^{\circ} \mathrm{C}$ until use. Those samples were processed according to the four DNA extraction methods as described below.

\section{TNES buffer method (Christoforou et al., 2017)}

Frozen egg masses were crushed and ground to make a powder using a mortar and pestle. The ground sample was added with TNES buffer (50 mM Tris- $\mathrm{HCl}, \mathrm{pH}$ 7.5, $400 \mathrm{mM} \mathrm{NaCl}, 100 \mathrm{mM}$ EDTA, pH 8.0 and $0.5 \%$ SDS, Proteinase $\mathrm{K}(20 \mathrm{mg} / \mathrm{mL})$ and incubated $2 \mathrm{hr}$ at $50{ }^{\circ} \mathrm{C}$ with shaking. Then microcentrifuge tubes $(1.5 \mathrm{~mL})$ were centrifuged at $12,000 \mathrm{rpm}$ for $5 \mathrm{~min}$ and the supernatant was decanted to a fresh tube and it was added with an equal volume of phenol: chloroform: IAA (25:24:1). Samples were vortexed vigorously for $10 \mathrm{~s}$ and centrifuged for $2 \mathrm{~min}$ at room temperature. The supernatant was collected and 2.5 volumes of ice cold $100 \%$ ethanol was added and placed in crushed dry ice for $5 \mathrm{~min}$. To remove supernatant, samples were centrifuged for $10 \mathrm{~min}$ at 12,000 $\mathrm{rpm}$. Finally, 70\% ethanol $1 \mathrm{~mL}$ was added into the sample contained microcentrifuge tubes $(1.5 \mathrm{~mL})$ and centrifuged for $5 \mathrm{~min}$ at 13,000 rpm to remove supernatant. Remain DNA was air dried for $15 \mathrm{~min}$ and re-suspended in $20 \mu \mathrm{L}$ of TE buffer.

\section{Modified CTAB method (Mondino et al., 2015)}

Egg masses were ground in liquid $\mathrm{N}_{2}$ to a fine powder. Then samples were added with $200 \mu \mathrm{L}$ homogenization buffer $(0.1 \mathrm{M}$ Tri $\mathrm{HCl}, 0.4 \mathrm{M} \mathrm{NaCl}$, $20 \mathrm{mM}$ EDTA at $\mathrm{pH} 8.0$ ) and incubated at $37^{\circ} \mathrm{C}$ for $15 \mathrm{~min}$. Next, the same sample was filled with 100 $\mu \mathrm{L}$ of extraction buffer (7\% CTAB, 1\% PVP, $0.1 \mathrm{M}$ Tris HCl, $1.4 \mathrm{M} \mathrm{NaCl}, 20 \mathrm{mM}$ EDTA at pH 8.0), 300 $\mu \mathrm{L}$ of $20 \%$ SDS and $0.5 \%$ of 2 - mercaptoethanol and mixed by inverting. Nematode egg mass samples with extraction buffer were incubated at $65{ }^{\circ} \mathrm{C}$ for $1 \mathrm{hr}$. Two times phenol: chloroform: IAA (25:24:1) separation was carried out. The supernatant was treated with Protinase $\mathrm{K}(10 \mathrm{mg} / \mathrm{mL})$ for $15 \mathrm{~min}$ at $37{ }^{\circ} \mathrm{C}$. Again chloroform: isoamyl alcohol (24:1) was perform to remove proteins. For DNA reprecipitate, samples were added with $0.6 \mathrm{x}$ volume of ice cold $70 \%$ ethanol and $0.5 \mathrm{x}$ volume $7.5 \mathrm{M}$ of ammonium acetate at $\mathrm{pH} 7.7$ and kept at $23^{\circ} \mathrm{C}$ for $30 \mathrm{~min}$ and centrifuged for $20 \mathrm{~min}$ at 10,000 rpm. Finally, the pellet was washed in $70 \%$ ethanol, air dried and re-suspend in $20 \mu \mathrm{L}$ TE buffer.

\section{Phenol/Chloroform method (Khanal., 2014)}

Egg masses were placed on a $10 \mu \mathrm{L}$ drop of sterile distilled water on a glass slide and diced under a microscope using a sterile surgical blade. Fragments were transferred to microcentrifuge tube $(1.5 \mathrm{~mL})$ containing $50 \mu \mathrm{L}$ of lysis buffer $(1 \%$ SDS, 50 mM EDTA pH 8.5, 100 mM Tris $\mathrm{HCl} \mathrm{pH} \mathrm{8.5,}$ $100 \mathrm{mM} \mathrm{NaCl}, 100 \mu \mathrm{g} / \mathrm{mL}$ Proteinase K, 1\% 2mercaptoethanol). The egg mass lysate was frozen at $-80{ }^{\circ} \mathrm{C}$ for $40 \mathrm{~min}$, thawed on ice and incubated at $60{ }^{\circ} \mathrm{C}$ for $40 \mathrm{~min}$ with occasional agitation. The tubes were centrifuged at 13,000 rpm for $3 \mathrm{~min}$. Then an equal volume of phenol - chloroform: IAA (50:50) was added to the supernatant and vortex for about $2 \mathrm{~min}$ to form an emulsion. Then the tube was centrifuged at $13,000 \mathrm{rpm}$ for $10 \mathrm{~min}$ and the aqueous phase was transferred. Then $1 / 10$ volume of NaOAc ( $3 \mathrm{M}, \mathrm{pH} 5.2$ ) and 2.5 volume of ice cold $100 \%$ ethanol were added to the final aqueous phase and incubated the tube at $-20{ }^{\circ} \mathrm{C}$ overnight. They were centrifuged at 13,000 rpm for $30 \mathrm{~min}$ at $4^{\circ} \mathrm{C}$. The supernatant was removed and allowed to dry and the DNA pellet was dissolved $20 \mu \mathrm{L}$ of TE buffer.

\section{1\% SDS method (Waeyenberge et al., 2000)}

Nematode egg masses were crushed using a glass micro pestle and fragments were transferred to sterilized microcentrifuge tube $(1.5 \mathrm{~mL})$ with 20 $\mu \mathrm{L}$ of lysis buffer (1\% SDS, 50 mM EDTA pH 8.5, $100 \mathrm{mM}$ Tris $\mathrm{HCl}$ pH 8.5, $100 \mathrm{mM} \mathrm{NaCl}, 10 \mathrm{mg} / \mathrm{mL}$ Proteinase $\mathrm{K}$ ) and homogenised by vortexing. Then the tubes were stored at $-20^{\circ} \mathrm{C}$ for $1 \mathrm{hr}$ and incubated at $65^{\circ} \mathrm{C}$ for $1 \mathrm{hr}$ and again incubated for $95{ }^{\circ} \mathrm{C}$ for $10 \mathrm{~min}$ to inactivate Proteinase $\mathrm{K}$. Then tubes were centrifuged at 13,000 rpm for $2 \mathrm{~min}$ and collected the supernatant that contains DNA. The extracted DNA was stored at $-20{ }^{\circ} \mathrm{C}$. 
Table 1: Details of the Meloidogyne specific primers.

\begin{tabular}{llll}
\hline Primer Code & Primer sequence 5'-3' & Specificity and source & \\
\hline 194 & TTAACTTGCCAGATCGGACG & Meloidogyne genus 5S-18S ribosome \\
195 & TCTAATGAGCCGTACGC & region (Blok et al.,1997) & \\
MI-F & GTGAGGATTCAGCTCCCCAG & Meloidogyne incognita specific SCAR \\
MI-R & ACGAGGAACATACTTCTCCGTCC & (Meng et al., 2004) &
\end{tabular}

\section{Assessing the quantity/quality of extracted DNA and the success of the extraction}

The integrity of extracted DNA was observed through agarose gel electrophoresis using 0.8\% agarose gel and the DNA concentration was quantified in all extracts by measuring absorbance at $260 \mathrm{~nm}$ with the Bio-spec nano spectrophotometer (Shimadzu, Japan). The quality of the extract was also assessed by absorbance ratios of 260/280 $\mathrm{nm}$ and 260/230 $\mathrm{nm}$ and subjecting to PCR.

PCR assay was carried out for Meloidogyne genus and $M$. incognita species using 194/195 that targeting the non-transcribed spacer region between the $5 \mathrm{~S}$ and $18 \mathrm{~S}$ rDNA genes (Blok et al., 1997) and MI-F/MI-R which is species specific SCAR primer respectively (Table 1) (Meng et al., 2004) PCR amplification was carried out in a $25 \mu \mathrm{L}$ reaction mixture containing $3.5 \mu \mathrm{L}$ of nuclease free water, $1 \mu \mathrm{L}$ of BSA, $1 \mu \mathrm{L}$ of $\mathrm{MgCl}_{2}, 2 \cdot 5 \mu \mathrm{L}$ of each 10 $\mu \mathrm{m}$ forward and reverse primers and $12.5 \mu \mathrm{L}$ Promega PCR master mix (Promega, USA) for $2 \mu \mathrm{L}$ of 1:9 diluted template DNA. Then tubes centrifuged briefly to ensure that the reaction contents were mixed before placed on the thermal cycler (TAKARA, Japan).

PCR amplification was carried out using cycling conditions of $94^{\circ} \mathrm{C}$ for $2 \mathrm{~min}$, followed by 45 cycles of $94{ }^{\circ} \mathrm{C}$ for $30 \mathrm{sec} .55^{\circ} \mathrm{C}$ for $30 \mathrm{sec}$ (for $194 / 195$ primers) and $62{ }^{\circ} \mathrm{C}$ for $30 \mathrm{sec}$ (for MI-F/MI-R primers), $72{ }^{\circ} \mathrm{C}$ for $1 \mathrm{~min}$ and a final extension at 72 ${ }^{\circ} \mathrm{C}$ for 7 min (Adam et al., 2007). Amplified products were separated using gel electrophoresis in $2 \%$ agarose gel and $1 \mathrm{x}$ TBE buffer (89 mM Tris-borate, $2 \mathrm{mM}$ EDTA) at $50 \mathrm{~V}$, followed by gel documentation system (Enduro ${ }^{\mathrm{TM}}$ GDS, USA) after staining with ethidium bromide $(10 \mathrm{mg} / \mathrm{ml})$.

\section{RESULTS AND DISCUSSION}

Quantity and quality of extracted DNA by the four different protocols are given in Table 2. Even though the quantity of DNA resulted in by the modified CTAB method was the highest but the purity of the DNA (i.e., OD 260/280) was not satisfactory. The OD values lower than 1.8 for $260 / 280$ and $260 / 230$ are due to contamination of the extracted DNA with proteins and polysaccharides (Lucena-Aguilar et al.,2016). In contrast, both quantitative and qualitative parameters were at an acceptable level in the DNA extracted by $1 \%$ SDS method (Table 2). Among the tested protocols, intact genomic DNA was resulted in only by $1 \%$ SDS method, once integrity of DNA was checked by agarose gel electrophoresis (Figure 1).

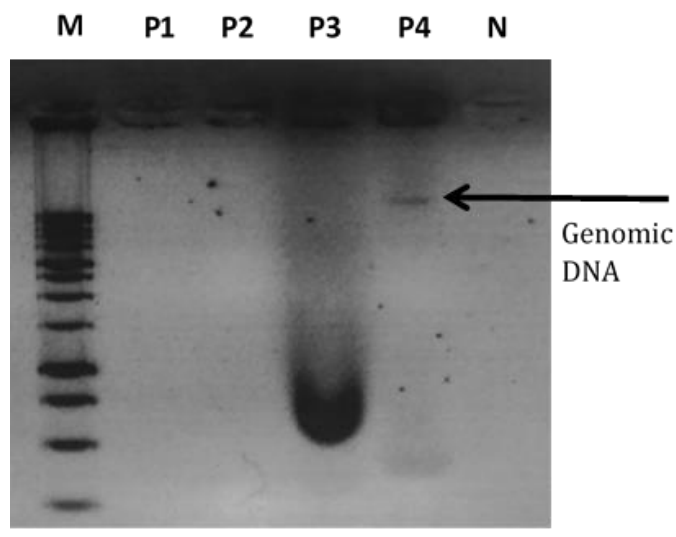

Figure 1: Extraction of genomic DNA by different protocols; M- 1 Kb DNA size marker, P1-TNES buffer method, P2-Modified CTAB method, P3-Phenol/Chloroform method, P4$1 \%$ SDS method.

Out of the four DNA extraction protocols used in the present study, P1, P2 and P3 were based on phenol/chloroform -based extraction. Although pure genomic DNA is obtained by this technique, toxicity of phenol, longer time involvement, high speed centrifugation steps of longer durations and labour-intensity are disadvantages. These could be the reasons for resulting in degraded DNA by P3 method (Figure 1). 
Table 2: Readings related to quantitative and qualitative parameters given by the DNA extracted by four different protocols.

\begin{tabular}{lcccc}
\hline Reading & TNES method & $\begin{array}{c}\text { Modified CTAB } \\
\text { method }\end{array}$ & $\begin{array}{c}\text { Phenol/chloroform } \\
\text { method }\end{array}$ & $\begin{array}{c}\text { 1\% SDS } \\
\text { method }\end{array}$ \\
\hline DNA quantity ng/ $\mu \mathrm{l}$ & 14.61 & 49.43 & 26.58 & 35.16 \\
OD 260/280 & 0.65 & 0.75 & 0.58 & 1.67 \\
OD 260/230 & 0.25 & 0.23 & 0.52 & 0.09 \\
\hline
\end{tabular}

Phenol/chloroform extraction has the possibility of losing extractable DNA and it could be a reason for the absence of DNA when extracted by the P1 and P2 methods (Figure 1). Moreover, presence of phenol in extracted DNA samples interferes with the quantitation of DNA detected by UV absorbance since phenol shows a very high extinction coefficient at $260 \mathrm{~nm}$ (Santella, 2006; Javadi et al., 2014). This situation overestimates the DNA concentration in samples. It could be a reason for the absence of detectable DNA bands in the agarose gel for samples P1 and P2 (Figure 1) despite the OD values given spectrophotometrically (Table 2 ).

In contrast, $1 \%$ SDS method (P4) used in the study is a method free from phenol/chloroform extraction and it is based on salting out (Javadi et al. (2014). Here, direct lysis of the cells has been done with SDS treatment and it yielded a higher quantity of DNA due to less cleaning steps and less wastage of extracted DNA. The extracted DNA available in the supernatant by $1 \%$ SDS method can be used directly for PCR. Further, salting out based DNA extraction protocols are considered as fast and inexpensive option to extract genomic DNA, especially in resource-limited conditions (Santella, 2006; Javadi et al., 2014).

Lower purity of all the DNA samples extracted by the four protocols could be attributed to the contamination of the samples with proteins and polysaccharides. Gelatinous matrix of the egg masses of Meloidogyne spp. is composed of a tanned protein and a carbohydrate (Sharon and Spiegel (1993). According to Sharon and Spiegel (1993), a complete protein digestion cannot be achieved through Proteinase $\mathrm{K}$ and trypsin has reported to be a better proteolytic enzyme in this regard. Therefore, the protein contamination could have been minimized and the purity of the samples could have been improved, if trypsin or a combination of Proteinase $\mathrm{K}$ and trypsin is incorporated for digestion of proteins.

According to Sakai (2010), $0.1 \%$ SDS concentration is sufficient for lysis of second-stage juveniles of $M$. incognita. However, in the present study, a higher concentration (1\%) of SDS was used to extract DNA from the egg masses of root knot nematodes due to the presence of tanned proteins in the gelatinous matrix in the egg masses.

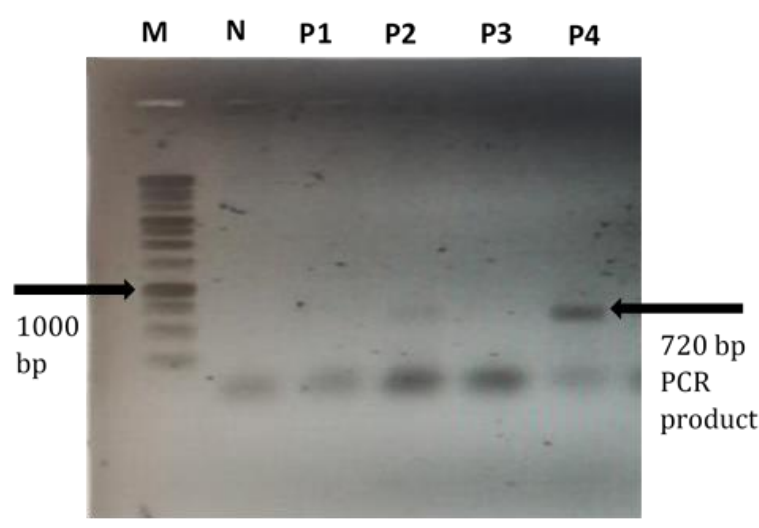

Figure 2: Amplified PCR product using the 194/195 primer pair with DNA extracted by different methods: M-1 kb DNA size marker, Nnegative sample, P1-TNES buffer method, P2Modified CTAB method, P3Phenol/Chloroform method and P4- 1\% SDS method.

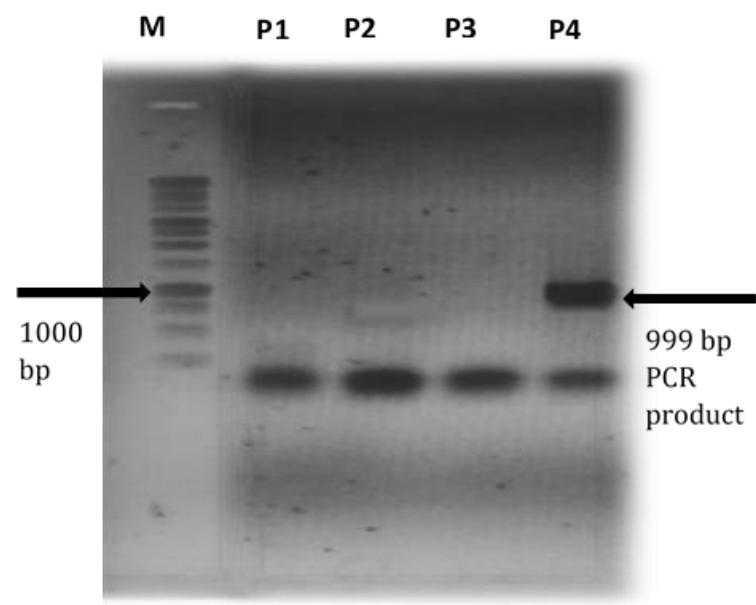

Figure 3: Amplified PCR product using the MIF/MI-R primer pair with DNA extracted by different methods: M-1 kb DNA size marker, P1TNES buffer method, P2-Modified CTAB method, P3- Phenol/Chloroform method and P4- 1\% SDS method. 
The PCR amplification using the primer pairs 194/195 and MI-F/MI-R resulted in clear expected fragments of about $720 \mathrm{bp}$ and $999 \mathrm{bp}$ (Adam et al., 2007) respectively (Figures 2 and 3) with the DNA extracted by $1 \%$ SDS method. The modified CTAB method resulted in a faint band for 194/195 primer pair but this DNA sample will be less effective in downstream molecular applications. Our results agree with Qiu et al., (2006), who have observed very faint PCR bands in a DNA sample of M. javanica second stage juveniles, prior to purification by sucrose centrifugal flotation but better amplification of the expected bands after the purification step. Therefore, the lower purity of the template genomic DNA sample could be a contributing factor for the less successfulness of PC

Higher purity and intact nature of the DNA sample by $1 \%$ SDS method could be the reasons for the successful amplification of the PCR product. As 1\% SDS method does not involved DNA precipitation and phenol/chloroform extraction steps it can be directly used for PCR amplification. Saki (2010) has stated this as a rapid and successful method, though a crude extract containing SDS is used for PCR reaction. Also, Donn et al. (2008) reported that DNA extraction of nematodes using lysis mixtures

\section{REFERENCES}

Adam, M.A.M., Phillips, M.S. and Blok, V.C. (2007). Molecular diagnostic key for identification of single juveniles of seven common and economically important species of root-knot nematode (Meloidogyne spp.). Plant pathology, 56(1), 190-197. doi: 10.1111/j.13653059.2006.01455.x

Blok, V.C., Phillips, M.S. and Fargette, M. (1997). Comparison of sequences from the ribosomal DNA intergenic region of Meloidogyne mayaguensis and other major tropical root-knot nematodes. Journal of Nematology, 29(1), 16. doi: $10.1163 / 156854102760402559$

Bogale, M., Baniya, A. and DiGennaro, P. (2020). Nematode Identification Techniques and Recent Advances. Plants, 9(10), 1260. doi: $10.3390 /$ plants 9101260

Brito, J., Powers, T.O., Mullin, P.G., Inserra, R.N. and Dickson, D.W. (2004). Morphological and molecular characterization of Meloidogyne mayaguensis isolates from Florida. Journal of Nematology, 36(3), 232. containing the detergent SDS yielded both quantifiable DNA and PCR product.

\section{CONCLUSION}

This study identified a relatively simple, less time consuming and efficient genomic DNA extraction method which can be conducted without using toxic organic compounds(1\% SDS, $50 \mathrm{mM} \mathrm{EDTA} \mathrm{pH}$ 8.5, $100 \mathrm{mM}$ Tris $\mathrm{HCl} \mathrm{pH} \mathrm{8.5,} 100 \mathrm{mM} \mathrm{NaCl}, 10$ $\mathrm{mg} / \mathrm{mL}$ proteinase $\mathrm{K}$ ) for root knot nematode egg masses. The method is suitable for routine DNA extractions and when large number of samples are handled. It was successful for PCR amplification using a set of genus-specific and species-specific primers to identify root knot nematodes (Meloidogyne incognita) and it assists in the applications of population studies of root knot nematodes.

\section{ACKNOWLEDGMENT}

The authors are grateful to Dr. A.K Udawasala and Mrs. D.M.K.K. Dissanayaka for technical advice and help during the completion of the project.

Chacon-Cortes, D., Haupt, L.M., Lea, R.A. and Griffiths, L.R. (2012). Comparison of genomic DNA extraction techniques from whole blood samples: a time, cost and quality evaluation study. Molecular Biology Reports, 39(5), 59615966.

Christoforou, M., Orford, M. and Tsaltas, D. (2017). Molecular Diagnostic Tools for Nematodes. Nematology-Concepts, Diagnosis and Control, $37 . \quad$ doi: 10.5772/intechopen.69075

Cliff, G.M. and Hirschmann, H. (1985). Evaluation of morphological variability in Meloidogyne arenaria. Journal of Nematology, 17(4), 445.

Donn, S., Griffiths, B.S., Neilson, R. and Daniell, T.J. (2008). DNA extraction from soil nematodes for multi-sample community studies. Applied Soil Ecology, 38(1), 20-26. doi: 10.1016/j.apsoil.2007.08.006

Eisenback, J.D., Sasser, J. and Carter, C. (1985). Diagnostic characters useful in the identification of the four most common species of root-knot nematodes (Meloidogyne spp.). An Advanced Treatise on Meloidogyne, 1, 95-112. 
Javadi, A., Shamaei, M., Ziazi, L.M., Pourabdollah, M., Dorudinia, A., Seyedmehdi, S.M. and Karimi, S. (2014). Qualification study of two genomic DNA extraction methods in different clinical samples. Tanaffos, 13(4), 41.

Khanal, C. (2014). Identification of Root-knot Nematodes (Meloidogyne spp.) of Arkansas using Molecular Diagnostics. M.Sc. Thesis, University of Arkansas, USA. 73.

Lucena-Aguilar, G., Sánchez-López, A.M., BarberánAceituno, C., Carrillo-Avila, J.A., López-Guerrero, J.A. and Aguilar-Quesada, R. (2016). DNA source selection for downstream applications based on DNA quality indicators analysis. Biopreservation and Biobanking, 14(4), 264-270. doi: 10.1089/bio.2015.0064

Meng, Q.P., Long, H. and Xu, J.H. (2004). PCR assays for rapid and sensitive identification of three major root-knot nematodes, Meloidogyne incognita, $M$. javanica and $M$. arenaria. Acta Phytopathologica Sinica, 34(3), 204-210

Mondino, E.A., Covacevich, F., Studdert, G.A., Pimentel, J.P. and Berbara, R.L. (2015). Extracting DNA of nematodes communities from Argentine Pampas agricultural soils. Anais da Academia Brasileira de Ciências, 87(2), 691697. doi: 10.1590/0001-3765201520130110

Qiu, J.J., Westerdahl, B.B., Anderson, C. and Williamson, V.M. (2006). Sensitive PCR detection of Meloidogyne arenaria, M. incognita, and $M$. javanica extracted from soil. Journal of Nematology, 38(4), 434
Sakai, H. (2010). A DNA extraction method with SDS from single nematodes for direct application to PCR amplification. Nematological Research (Japanese Journal of Nematology) 40(1), 1314. doi: $10.3725 / \mathrm{jjn} .40 .13$

Santella, R.M. (2006). Approaches to DNA/RNA extraction and whole genome amplification. Cancer Epidemiology and Prevention Biomarkers, 15(9), 1585-1587. doi: 10.1158/1055-9965.epi-06-0631.

Sharon, E. and Spiegel, Y. (1993). Glycoprotein characterization of the gelatinous matrix in the root-knot nematode Meloidogyne javanica. Journal of Nematology, 25(4), 585.

Sikora, R.A., Coyne, D.L., Hallmann, J. and Timper, P. (2018). Plant Parasitic Nematodes in Subtropical and Tropical Agriculture. $3^{\text {rd }}$ Ed., CABI International and USDA, 876

Villar-Luna, E., Goméz-Rodriguez, O., RojasMartínez, R.I. and Zavaleta-Mejía, E. (2016). Presence of Meloidogyne enterolobii on Jalapeño pepper (Capsicum annuum L.) in Sinaloa, Mexico. Helminthologia, 53(2), 155-160. doi:10.1515/helmin-2016-0001

Waeyenberge, L., Ryss, A., Moens, M., Pinochet, J. and Vrain, T. (2000). Molecular characterisation of 18 Pratylenchus species using rDNA restriction fragment length polymorphism. Nematology, 2(2), 135-142. doi: $10.1163 / 156854100509024$ 